\title{
INTEGRATING ONLINE TEACHING ENGLISH AS A FOREIGN LANGUAGE
}

\author{
Natalia Ivanova \\ Pskov Branch of the Academy of Federal Penal Service of Russia, \\ Russian Federation
}

\begin{abstract}
Online education/e-learning has been increasingly adopted globally as it has served as the only tool accessible for teachers and students to maintain undisrupted learning during the coronavirus outbreak. The relevance of the article is determined by the need to define effective ways to implement online education in foreign language classes to produce a positive effect on the learning outcome. The purpose of the article is to present ways of providing English-as-a-foreign-language learners with an online course designed in the learning management system Moodle and aimed at enhancing students' foreign language skills. The work uses a logical method (theoretical), the study of the experience of educational organizations and personal pedagogical experience at Pskov Branch of the Academy of Federal Penal Service of Russia (empirical). The study described the diversity of Moodle structure particular tasks, its assessment procedure and present military students' feedback about the impact of the course on their foreign language acquisition, developing learners' autonomy and soft skills. It explored what problems English-as-a-foreign-language learners had with their English language learning and what support they needed to gain the maximum benefits from the online learning environment. The outcome of the online education was a substantial increase in the learners' autonomy and an integrative development of foreign language skills and soft skills.
\end{abstract}

Keywords: e-learning, foreign language skills, Moodle, online education, soft skills.

\section{Introduction}

In line with the global challenge of the 21st century in the form of Covid19 pandemic higher education institutions and schools around the world face the challenges of carrying forward teaching activities completely online. This paper presents a case study of the process of transmission from face-to-face learning model to quality e-learning within a short period time. Having implemented e-learning into language education context, language teachers of the Faculty of Law of Pskov Branch of the Academy of Federal Penal Service of Russia designed an online course based on the Moodle platform. A set of interactive tasks, quizzes, mid-term and final tests, polls, using various web-services and digital educational tools have been developed and integrated in the EFL education process.

The current research work is aimed at providing an in-depth look at the 
situation of EFL teaching and learning in the Russian context during the Covid19 pandemic by analyzing the impact of the online English course on the military students' foreign language acquisition, developing learners' autonomy and soft skills.

In this study, a survey was conducted in an individualized exchange format to collect data in order to answer the research questions: What problems English-as-a-foreign-language learners had with their English language learning, what support they needed to gain the maximum benefits from the online learning environment, what methods, technologies and digital tools have been crucial in building up of the learners' autonomy and an integrative development of their foreign language skills and soft skills.

\section{Literature Review}

In the digital area of the modern world traditional lecture-based education has given way to popular and effectively applied learning models: ComputerAssisted Language Learning (CALL), flipped/blended learning (Bergmann \& Sams, 2012), Mobile-Assisted Language Learning (MALL) (Andujar, SalaberriRamiro, \& Martínez, 2020). The role of digital devices like computers, smartphones, tablets or Personal Digital Assistants (PDAs) applied to foreign language learning imply a number of advantages: providing learning environment to study anytime and anywhere as you like besides the classroom; facilitating real and virtual human interaction; building up language skills and soft skills concerned with abilities to make research and study on your own; developing higher learner autonomy, enhancing students' participation and motivation in educational process.

In fact, electronic learning (e-learning) relies on the models like The Computer Assisted Language Learning (CALL) and is a key component of courses offered by educational institutions worldwide nowadays. E-learning refers to a distance learning process which involves many aspects of the information society (Kakoty, Lal, \& Sarma, 2011). Although e-learning does sometimes refer to blended learning, or a combination of online and face-to-face teaching, it is generally seen as the specific development of distance education using information and communication technologies (ICT) to deliver education to remote learners (Vaona et al., 2018). E-learning is a pedagogical tool which promotes more individualized, active and cooperative learning. Knowledge is no longer transferred from an authority but constructed within an open, changing and dialogic context, enabling the development of the collective intelligence (Levy, 2000). It was found that a huge array of resources can be of help for teachers and learners to gain their knowledge in an open context of virtual learning environment (VLE). The open schools (e.g. India's National Institute of 
Open Schooling; the New Zealand Correspondence School) and open universities (e.g. The UK Open University; Athabasca University, Canada) can provide the variety of high-quality available courses and greater flexibility in the use of time and resources to help students get back on track (Daniel, 2020). Furthermore, teachers discuss the advantages of incorporating digital educational tools such as web-services: Quizlet, Learning Apps, Wiser.me, WordSift to the educational process, which provide students with means to master professional English and operate it successfully in future professional activity while communicating and collaborating with foreign colleagues (Perevalova, Resenchuk, \& Tunyova, 2020). Additionally, researchers have proven positive students' learning experience and technological acceptance of a blended learning model through mobile devices (Andujar et al., 2020; Yu, Ally, \& Tsinakos, 2017; Hsieh, Wu, \& Marek, 2017). It was noted that social platforms like Facebook, Twitter, Whatsapp, YouTube, and Instagram have become the refuge of teachers and students during the last years. However, there are many educational platforms like Moodle which bring the same services to the learners but in an academic setting. Current surveys also point out that in vocational schools, ICTs (electronic courses within the Moodle platform in particular) could be used for activating and facilitating teaching and learning, saving time, and promoting individualized student-centered learning when compared with traditional teaching (Shamim \& Raihan, 2016).

Moodle LMS is one of the best known virtual learning environments used at European universities that enables teachers to provide both Face-to-Face (FtF) teaching and online learning. One of the benefits of VLE is that it affords students to access the course material at any time, which especially suits parttime students who are motivated by the instant feedback provided by online assessments. VLE includes a number of various tools, such as email, chat, discussion boards, etc. It also involves testing through specially designed tasks (Bielousová, 2020).

It was found that many online teaching platforms, techniques, and novel approaches are widely accessible to students who undoubtedly benefit from the fast acquisition of knowledge and information (Huang, Chen, \& Lin, 2009; Boćković, Gajić, \& Tomić, 2014; Bielousová, 2020). Furthermore, the results of the latest research (Bielousová, 2020; Bilotserkovets \& Gubina, 2019) demonstrate that applying e-learning technologies into the process of teaching languages has proven to be successful, as they contribute to the development of special language competencies within the context of special disciplines.

Nevertheless, relevant research concerned with the integration of e-learning in educational process shows that virtual learning environment encounters a lot of negative attitudes on the part of students (Bilotserkovets \& Gubina, 2019; Zhang, 2019). 
As S. Zhang noted, self-regulated learning (SRL) is especially important in blended/flipped learning environments (Zhang, 2019). Furthermore, e-learning environment is based on the concept of self-regulated learning and is considered to be a set of proactive processes that students use to acquire learning skills, such as setting goals, selecting and using strategies, self-monitoring effectiveness of learning, and self-evaluating the learning outcomes. Therefore, SRL plays a critical role in students' learning and is key to the question of how students become masters of their own learning (Zimmerman, 2008). In the study of the use of SRL in a specific language learning context (Zhang, 2019) is concluded that the students had different problems in flipped/blended learning environments, and they would maximally benefit from online education if they had the opportunity to learn and incorporate SRL strategies such as goal-setting, planning, monitoring, and self-reflecting to facilitate their learning and improve their acquisition of the language.

Based on the research, despite the fact that implementation of e-learning model has not always proved its effectiveness clearly, the researchers involved in e-learning consider e-learning model to be the right way for further investigation to be done in the field. Thus, our study of virtual e-learning environment is aimed at defining and testing possibilities of the academic platform Moodle and other digital tools to develop and improve learners' special language competencies and soft skills, help them structure their learning environments to reduce distractions and reflect upon every step of the learning process in order to improve their SRL continuously.

\section{Methodology}

To analyse the effectiveness of the implemented online course of English, a set of research methods has been used, including: 1) theoretical analysis of pedagogical, socio-psychological, scientific-methodological and special professsional literature on the problem of research; 2) empirical questioning, testing and pedagogical experimenting. This method is used to determine the current state of foreign language communicative skills formation of future lawyers, and to verify the effectiveness of the online course introduced in the educational process; 3) methods of mathematical statistics. This uses statistical data processing for displaying information and for processing pedagogical experiment data and visual demonstration of experimental results. A sample of 20 first-year military students from Pskov Branch of the Academy of Federal Penal Service of Russia, the Faculty of Law was investigated with an opinion poll regarding their perception about the problems that the transition of the entire teachinglearning activity in the online environment raised for them. The pedagogical experiment took place in the period since February 2020 till June 2020. 


\section{Research Results}

The aim of the online course is to prepare military students to be ready for daily and professional communication in English at B1 and B2 level in accordance with the Common European Framework of Reference for Languages and the Federal State Educational Standards for Higher Education for the program 40.03.01 Law (Qualification (degree) bachelor).

As there is no Face-to-Face mode of learning, students face a new challenge in the form of virtual learning environment, where they start learning with a teacher giving stimuli, recommendations and comments on their work via chat or forum in Moodle or WhatsApp. To make this start easier, we introduced a questionnaire to find out the students' attitude towards the prospect of studying English at the Law faculty of Pskov Branch of the Academy, asked students to list in what spheres they could use English and also tested their level of English.

Having analysed military students' responses, we could infer that they were motivated to learn English intensively, since they understood clearly that the English language acquisition was required for successful communication and it would be useful in further professional practices. However, only $20 \%$ of the respondents stated that they referred to linguistic dictionaries and reference books in learning English, while 25\% read authentic texts and listened to podcasts during training, which is not an optimistic fact.

The second part of the survey contained questions about the problems which students faced in English language learning and about the self-regulative strategies in learning.

Having analysed the students' answers, we found out that $70 \%$ of the students had problems with grammar patterns and $90 \%$ with listening part and, as they felt frustrated, $50 \%$ of the students postponed the task and $10 \%$ of the students neglected the task as it was too difficult for them.

Thus, the first stage of the experiment demonstrated that the problems of foreign language communicative competence forming and self-regulative strategies development had to be addressed in the online course.

As we had to stop off-line education and proceed with an online course in Moodle, we conducted an experiment in two groups of first-year military students majoring in Law. In an experimental group ( $\mathrm{N}=20)$ new informative and communicative technologies, project method and case-study technology were used while the other students $(\mathrm{N}=18)$ had e-learning classes based on the traditional methods of teaching. The pre-test on English in both groups showed the foreign language communicative competence formation of first-year students was mostly of the medium and low levels.

The experiment lasted for a term. For the experiment we have chosen the following themes: "Government system of the English-speaking countries", 
"International cooperation of the police", "Alternative Sanctions". All the military students studied the same themes. The purpose of the experiment was the integrative development of the learners' English language skills and soft skills which correspond with the foreign language communicative competence and synchronous development of their self-regulative strategies which was reflected in methodological structure of the online course and its contents.

The materials on the Moodle were grouped by themes and divided into three blocks: regulative, training and assessment/score. The regulative block contained syllabus of the course with detailed description of the aim and structure of training, internet resources and e-books, assessment criteria, examination requirements, news. The training block had a thematic structure of modules which included the name of the theme, theoretical multimedia presentations and videos, a variety of learning tasks with deadlines, exercises, projects, case-studies with applied references on the internet resources (sites, videos, texts), tests, quizzes. The assessment/score block was an effective tool to see how well the students progressed in their studies.

While speaking was one of the most difficult aspects of English to be improved within the online course in the Moodle, we decided to use WhatsApp for oral communication with students. It was both group work and individual sessions with each of the students.

Taking into consideration that e-learning implies students' autonomous learning, we have specified technologies that would emphasise military students' ability to accumulate knowledge through discourse, discussion, sharing of perspectives and sources, analysis of resources from multiple sources, and teacher's feedback. Having analysed numerous pedagogical technologies, we came to the conclusion that the use of information and communication technologies, integrative technologies like project method and case-study technology would enable learners to become participants of their quasi professional activity, enhance in-job training of future lawyers.

The education process of teaching English as a foreign language is contentbased and relies on different teaching methods. One of the most effective tools for legal education is the technology of case-study which implies the design of learning cases/problem issues, tasks which are offered to students to be solved within the educational process of a certain subject. Case-study technology and project method are known to be integrative technologies which should be used in classes of English at the final stage of studying a theme as they require student's independent work and sufficient knowledge in the area of studies to be able to conduct autonomous research and analyse information.

While studying the theme "Alternative Sanctions" students were provided with texts, exercises and tests in Moodle. The next home assignment was to read the script of the video "Judiciary Now: You be the Judge - Sentencing Scenario 
for Students" on the site youtube.com, study the vocabulary and complete a few tasks to check the understanding of the video content. The subsequent step after the discussion of the script via WhatsApp and chat in Moodle was watching a video. As watching video followed reading for details and discussion of the problematic issues, it caused no difficulties for the students and was enjoyed by them.

Then the students were offered some practical cases, related to certain moral and ethical issues: murder, committed by a teenager and continuous teenager's abuse, assault and battery, committed by his mother, murder, committed in the heat of passion and so on. To be ready for the discussion of the given practical cases in class, the students were divided into two groups- those who were for traditional long-term sentences and those who were for alternative sanctions. Both groups were asked to give comments on the crimes and propose proper sanctions for offenders. At the class the first group was asked to present their views on one of the issues and provide their arguments. The second group was to follow it and provide their counter arguments. As soon as the arguments were downloaded into the chat/forum system, discussion via WhatsApp took place where the students debated and had a real talk on the matter.

The teacher's role was limited to providing help in case of misunderstanding, correcting if there were errors in communication and commenting on the rules of communication, if needed, summing up and reflexing at the end of the class.

Practical cases concerned with the theme: Government system of the English language countries were represented by biographies of different people. To solve the case one needed to analyse the provided information about notable candidates to run for president and choose the appropriate person. Students had to write their ideas and argumentation for a candidate in chat/forum. Then communication was switched into group talk via WhatsApp format where students could express their arguments and listen to each other. The teacher's role was to help students in their talk, read the chat and give comments and correct students' speech and messages.

Another innovative technology aimed at developing person's talents and abilities is the project method. The project work on the theme "International police cooperation" implied autonomous students' analysis of different types of crime which are investigated by the international police force like Interpol. The students were asked to make research in the provided web resources and make a short presentation of a certain type of crime and the police activities to stop and prevent it. As a result of this work students could share their multimedia presentations, peer review them and choose the most original and interesting one. 
The introduction of modern forms of Edutainment which is the combination of education and entertainment into the e-learning system is a prerequisite of successful education as it helps to create a comfortable background in the process of learning, turning it into action, mock role play in which not only a teacher takes part, but all the students participate in it. This is what edutainment is. Therefore, apart from project method and case-study technology, we used Quizlet, an entertaining learning resource which creates interactive learning tasks.

To see the results of the experiment and assess the formation of the foreign language communicative competence in its four aspects (writing, speaking, vocabulary, grammar), experimental and control groups of students were offered sets of 10 questions (tests, communication tasks) for each selected aspect. The level of the foreign language communicative competence, achieved by the military students, was measured on a 10-point scale. Accordingly, the intermediate score is a reflection of the number of correctly completed tasks within each of the aspects of the foreign language task. The final score was formed as a grade-point average (it is also the calculated grade-point average in our case, since the authors considered the contribution of each of the aspects to be equivalent). The results of the experiment are presented in Tables 1-2.

Table 1 The Measurement Results on the Themes

\begin{tabular}{|l|c|c|c|c|c|c|}
\hline \multirow{2}{*}{$\begin{array}{l}\text { Foreign } \\
\text { language } \\
\text { aspects }\end{array}$} & \multicolumn{2}{|c|}{$\begin{array}{c}\text { "Government system of the } \\
\text { English speaking countries” }\end{array}$} & \multicolumn{2}{|c|}{$\begin{array}{c}\text { "Alternative } \\
\text { sanctions” }\end{array}$} & \multicolumn{2}{|c|}{$\begin{array}{c}\text { "International police } \\
\text { cooperation” }\end{array}$} \\
\cline { 2 - 7 } & $\begin{array}{c}\text { Control } \\
\text { Group }\end{array}$ & $\begin{array}{c}\text { Experimen- } \\
\text { tal Group }\end{array}$ & $\begin{array}{c}\text { Control } \\
\text { Group }\end{array}$ & $\begin{array}{c}\text { Experimen } \\
\text {-tal Group }\end{array}$ & $\begin{array}{c}\text { Control } \\
\text { Group }\end{array}$ & $\begin{array}{c}\text { Experimen } \\
\text {-tal Group }\end{array}$ \\
\hline Writing & 8,8 & 9,6 & 8,5 & 9,5 & 8,4 & 9,5 \\
\hline Speaking & 7,5 & 9,1 & 7,2 & 9,2 & 7,9 & 9,4 \\
\hline Grammar & 8,6 & 9,6 & 8,4 & 9,3 & 8,5 & 9,5 \\
\hline Vocabulary & 8,4 & 9,1 & 8,6 & 9,7 & 8,3 & 9,4 \\
\hline Final Score & 8,3 & 9,3 & 8,2 & 9,4 & 8,3 & 9,4 \\
\hline
\end{tabular}

Table 2 Summary of the Experiment Results

\begin{tabular}{|c|c|c|}
\hline Themes & $\begin{array}{l}\text { Grade-point average of the } \\
\text { control group }\end{array}$ & $\begin{array}{l}\text { Grade-point average of the } \\
\text { experimental group }\end{array}$ \\
\hline $\begin{array}{c}\text { "Government system of the } \\
\text { English speaking countries” }\end{array}$ & 8,3 & 9,3 \\
\hline "Alternative sanctions” & 8,2 & 9,4 \\
\hline "International police cooperation” & 8,3 & 9,4 \\
\hline Final Score & 8,3 & 9,4 \\
\hline
\end{tabular}


While observing students' work in Moodle on different cases, projects, quizlet tasks, we noticed that students demonstrated higher activity in virtual classes, which indicated an increase in motivation and interest. The level of readiness for virtual classes had increased. As feedback, we used a survey in the form of a questionnaire: 1 . Were you interested in the material presented in the form of case-study, project work, quizlet? 2. How useful is this experience of learning with the help of case-study technology, project method, quizlet? 3. What did you personally get from learning based on the case-study technology, project method, quizlet? 4 . What difficulties did you have during your studies based on the case-study technology, project method, quizlet? Students were asked to give answers on a five-point scale, where "5" - the highest degree of interest, etc.,"1" - the lowest degree. For ease of analysis, the data were transferred to a dichotomous scale: 4-5 points - a high level of interest, etc., 1-3 points - a low level of the interest. The results of survey indicate a high level of interest in the case-study technology, project method and quizlet. All respondents of the experiment expressed the firm belief that the experience they received would be of help in their future studies and professional life.

Reflecting on the problems which the students had in e-learning, they noted that it was difficult to organize their own studies as there were no face-toface classes, but thinking about disadvantages of not completed home assignments and low academic grades and thanks to the teacher's emotional support and feedback forced them to change their strategy of learning: military students have learnt to be more self-organized and thoughtful about time management, plan studies and keep moving and achieving results, they have also tried to be more cooperative working in a team. Such soft skills as self organisation and cooperation were of great help to the learners and were developed in e-learning environment synchronously with the foreign language competence.

Comparing the level of foreign language communicative competence in both groups, the higher level of the foreign language communicative competence was formed in the experimental group. Thus, we have come to the conclusion that e-learning environment, based on the concepts of Edutainment, Self-Regulative Strategies of learning, communicative approach and in-job training can be effectively applied in foreign language teaching.

\section{Conclusions}

Integrating online teaching English as a foreign language into the educational process has become a challenging task for both teachers and students as both groups had to adopt to a new virtual learning environment.

E-learning environment, based on the concepts of Edutainment, Self- 
Regulative Strategies of learning, communicative approach and in-job training, has proven to be effective in foreign language teaching.

Purposeful inclusion of Edutainment technology resources in the e-learning environment as a motivational component allowed to increase the motivation of students to study in a distance format, which directly affected the formation of military students' foreign language communicative competence and soft skills.

A set of interactive academic tasks and the limited time for their fulfillment accompanied by the teacher's feedback on the students' academic progress and the warm and friendly atmosphere created by the teacher's stimuli contributed to effective and continuous development of military students' self-regulative strategies and formation of the communicative competence.

\section{References}

Andujar, A., Salaberri-Ramiro, M. S., \& Martínez, M. S. C. (2020). Sustainability 12, 1110. DOI:10.3390/su12031110

Bergmann, J., \& Sams, A. (2012). Flip Your Classroom: Reach Every Student in Every Class Every Day. International society for technology in education. Washington, DC, USA.

Bielousová, R. (2020). On the Issue of Adapting Materials for the English for Specific Purposes Online Course. Revista Romaneasca pentru Educatie Multidimensionala, 12(1Sup1), 60-76. DOI: https://doi.org/10.18662/rrem/12.1sup1/223

Bilotserkovets, M., \& Gubina, O. (2019). Target Language Teaching by Means of E-Learning: A Case Study. Revista Romaneasca pentru Educatie Multidimensionala, 11(4), 17-29. DOI:10.18662/rrem/154

Boćković, V., Gajić, T., \& Tomić, I. (2014). Moodle in English language teaching. Impact of Internet on Business activities in Serbia and Worldwide: Uticaj Interneta naposlovanje u Srbiji i svetu. Retrieved from: http://portal.sinteza.singidunum.ac.rs/Media/files/ 2014/480-483.pdf

Daniel, S.J. (2020). Education and the COVID-19 pandemic. Prospects, 49, 91-96. DOI: https://doi.org/10.1007/s11125-020-09464-3

Hsieh, C.J.S., Wu, W.C.V., \& Marek, M.W. (2017). Using the flipped classroom to enhance EFL learning. Comput. Assist. Lang. Learn, 30, 1-21.

Huang, H.C., Chen, C.L., \& Lin, C.C. (2009). EFL learners' use of online reading strategies and comprehension of texts: An exploratory study. Computers \& Education, 52(1), 1326. DOI: https://doi.org/10.1016/j.compedu.2008.06.003

Kakoty, S., Lal, M., \& Sarma S.K. (2011). E-learning as a research area; an analytical approach. Int. J. Adv. Comput. Sci.Appl, 2(9), 144-148.

Levy, P. (2000). Cyberculture and education. Pedagogy Knowledge, 14, $23-31$.

Perevalova, A., Resenchuk, A., \& Tunyova, N. (2020). Teaching Professional Vocabulary to the Students in Coal Region Universities through Digital Educational Tools. Vth International Innovative Mining Symposium. DOI: https://doi.org/10.1051/e3sconf/ 202017404051

Shamim, M.R.H., \& Raihan, M.A. (2016). Effectiveness of using ICTs to promoteteaching and learning in technical education: Case of Bangladesh. International Journal of Vocational and Technical Education, 8(2), 12-19.

Vaona, A., Banzi, R., Kwag, K. H., Rigon, G., Cereda, D., Pecoraro, V., Tramacere, I., \& 
SOCIETY. INTEGRATION. EDUCATION

Proceedings of the International Scientific Conference. Volume V, May $28^{\text {th }}-29^{\text {th }}$, 2021. 340-350

Moja, L. (2018). E-learning for health professionals. Cochrane Database Syst Rev. 2018, (1). Art. No.: CD011736. DOI: 10.1002/14651858.CD011736.pub2

Yu, S., Ally, M., \& Tsinakos, A. (2017). Mobile and Ubiquitous Learning: An International Handbook. Springer: New York, NY, USA.

Zhang, S. (2019). Chinese-as-a-foreign-language learners' use of self-regulated learning in flipped/blended learning environments: A descriptive study. Studies in Self-Access Learning Journal, 10(2), 181-204. Retrieved from: http://sisaljournal.org/archives/ jun19/zhang

Zimmerman, B. J. (2008). Investigating self-regulation and motivation: Historical background, methodological developments, and future prospects. American Educational Research Journal, Vol 45, Issue 1. DOI: https://doi.org/10.3102/0002831207312909 